\title{
Evaluation of Passive Stretching in the Hamstrings Flexibility of Who Practice Exercises
}

\author{
Luana Torres Monteiro Melo ${ }^{1, *}$, Renata dos Santos Vasconcelos ${ }^{2}$, Lísia Maria Santiago Andrade Teles ${ }^{3}$, \\ Larissa Mota Porto ${ }^{3}$, Julyana Almeida Maia ${ }^{4}$, Ana Paula Vasconcellos Abdon ${ }^{5}$
}

${ }^{1} \mathrm{PhD}$ student in Biotechnology at the State University of Ceara, Fortaleza, Ceara, Brazil

${ }^{2}$ Master of Medical Sciences from Federal University of Ceara, Fortaleza, Ceara, Brazil

${ }^{3}$ Bachelor of Physiotherapy from University of Fortaleza, Fortaleza, Ceara, Brazil

${ }^{4}$ Master of Public Health from University of Fortaleza, Fortaleza, Ceara, Brazil

${ }^{5} \mathrm{PhD}$ of Biotechnology from State University of Ceara, Fortaleza, Ceara, Brazil

\begin{abstract}
Objective: Does passive stretching before and after strength training effect the flexibility of the hamstrings in people who work out? Design: 40 healthy student volunteers, ranging in age from 18 to 35 years old, who work out were randomly divided into four groups, with group A stretching before and after working out, group B stretching just before working out, group $\mathrm{C}$ stretching only after working out, and group D abstaining from stretching. The hamstrings of each leg were stretched for 30 seconds. Results: A total of 40 students, of whom 24 (60.0\%) were women with a mean age of $23.3 \pm$ 4.18 years, were included in the study. Of that group, $34(85.0 \%)$ had done physical activity at another time. Their workout regimens were aimed at weight loss $(\mathrm{n}=12 / 30,0 \%)$, muscle gain $(\mathrm{n}=25 / 62,5 \%)$ and health maintenance $(\mathrm{n}=3 / 7,5 \%)$. The groups that engaged in stretching (A, B and C) experienced a significant increase in hamstring flexibility in the final evaluation $(\mathrm{p}<0.05)$, as compared to the group $\mathrm{D}$. This study did not find any variation in flexibility between the groups ( $>$ > 0.05). Conclusion: Passive stretching resulted in increased hamstring flexibility, most notably in group A, which stretched the hamstrings before and after workout.
\end{abstract}

Keywords Muscle Stretching Exercises, Joint Range of Motion, Resistance Training, Physical Therapy

\section{Introduction}

The practice of regular physical activity contributes to a more active lifestyle, is related to voluntary human behavior, and is determined by biological, psychological, sociological and cultural aspects $[1,2]$.

Many exercises can be used in sports and therapeutic environments for increasing flexibility, enhancing the performance of individuals, and rehabilitating athletes and sedentary people $[3,4]$.

Flexibility is an important component of physical conditioning programs as an adjunct to muscle strength and endurance training. A shortened muscle may create imbalance at joints and faulty postural alignment that may lead to injury and joint dysfunction. The hamstring muscles are an example of a muscle group that has a tendency to shorten and this reduced extensibility of the hamstrings could be associated with several clinical conditions of interest $[5,6]$.

Among these, muscle stretching is a type of exercise that

* Corresponding author:

luanatmelo@hotmail.com (Luana Torres Monteiro Melo)

Published online at http://journal.sapub.org/sports

Copyright $(\odot 2014$ Scientific \& Academic Publishing. All Rights Reserved tenses the soft tissue structures to enable greater mobility, leading to an increase in joint range of motion and flexibility. Besides reducing muscle tension, muscle stretching can help maintain satisfactory levels of mobility in joints $[7,8]$.

Among the various ways to stretch are: prolonged relaxation, dynamic or ballistic stretching and passive (static) stretching. Passive stretching is the safest and most commonly used form of stretching $[8,9]$.

The acute effect of passive stretching allows the excitability reduction of alpha motor neuron for low-speed, creating better adaptations of muscle and connective tissue, and promoting their mechanical properties [9].

When performed incorrectly, passive stretching can be a major cause of movement deficits. However, when done properly, it protects the joints and muscles, as it improves blood supply and keeps them healthy $[10,11]$. There are still questions surrounding the true influence of stretching and the ideal times to utilize it in relation to the functional performance of individuals, regardless of athletic ability.

Currently, passive stretching before exercises that require effort is not being done because the short duration may cause decreased muscle strength $[5,11]$. Instead, it has been recommended after physical activity, as it contributes to the maintenance of muscle-tendon flexibility $[5,12]$. 
Static stretching may not prevent injuries from high energy exercise, Potential high energy exercise injuries include fractures, joint dislocation and tearing of joints. However, static stretching can protect against injury sustained from low energy exercises, such as muscle strain, and it can reduce pain after exercise [13]. Moreover, there are studies showing that stretching before or after exercise has a direct effect on muscle soreness. However, this is a controversial topic among health professionals [12].

The present study aimed to analyze the influence of passive stretching before and after strength training on hamstring flexibility in people who workout at the gym.

\section{Methods}

\subsection{Design}

We conducted an interventionist, controlled, single blinded study developed at the Núcleo de Atenção Médica Integrada (NAMI), at the University of Fortaleza (UNIFOR), from December 2011 to March 2012.

\subsection{Participants, Therapists, Centers}

The sample consisted of 40 students who visited the gym regularly for 1 to 5 months. The subjects ranged in age from 18 to 35 years, and had no history of chronic disease or musculoskeletal injury.

This research adhered to the bioethical principles contained in Resolution 196/96 of the National Health Council [14], which regulates the ethical-legal aspects of research on humans. The research was approved by the Ethics Committee of UNIFOR according to opinion $n^{\circ}$ 294/2010. Before starting the study all participants were informed about the objectives, benefits, and risks included in the terms of consent.

\subsection{Intervention}

After selection, the participants went through an initial assessment to collect the following information: identification, amount and type of physical activity, and sit and reach test scores using the Wells bench.

The Wells bench was used to assess the flexibility of the hamstring muscle. In this test, a person sits on a mat, with the soles of both feet maintaining contact with a box. The top of the box has an indicator marked in centimeters that is used to measure flexibility by how far the person can push the indicator without bending the legs. The knees of the seated person are extended while the hips are flexed. The subject is then asked to take a deep breath, and during exhalation, flex the trunk forward with the upper limbs extended. The upper limbs are supported by a bench of $23 \mathrm{~cm}$ long aligned with a tape measure over the bench. During flexion of the trunk, the right hand is placed over the left and the tips of the fingers touch the indicator on top, and move it forward as far as possible.

\subsection{Outcome Measures}

After evaluation, the participants were randomly divided into four groups: A, B, C and D. Group A. stretched before and after workout ; group B stretched only before workout; group C stretched only after workout; and group D did not stretch at all.

Passive stretching of the hamstrings was performed only once, lasting 30 seconds [15], and initiated on the right leg. Participants were in supine position with head, trunk and arms aligned along the body. The researcher remained ipsilateral to the subject's leg being stretched and applied external force to the limit tolerated by the participant. The researcher performed a hip flexion, knee extension, and dorsiflexion of the ankle while the opposite leg remained extended on the ground.

Different researchers, seeking to standardize and blind stages of the research, performed the assessments and stretching procedure.

\subsection{Data Analysis}

The data were submitted for descriptive and inferential statistical analysis. To analyze the difference between the initial and final evaluations, the following tests were applied to each group: analysis of variance test (ANOVA), the paired $\mathrm{t}$ test, and the Kolmogorov-Smirnov test of normality. In addition, the Statistical Package for the Social Sciences (SPSS) version 17.0 was used. The level of significance was set at $5 \%(\mathrm{p}<0.05)$.

\section{Results}

This study evaluated 40 students with a mean age of $23.3 \pm$ 4.18 years, weight $67.1 \pm 12.26 \mathrm{~kg}$ and height of $1.67 \pm 0.90$ meters. Of those evaluated, $24(60 \%)$ were female and 34 $(85 \%)$ had engaged in physical activity at another time.

The purpose of working out, according to the participants, ranged from losing weight $(\mathrm{n}=12 / 30,0 \%)$ to gaining muscle $(\mathrm{n}=25 / 62,5 \%)$ and maintaining health $(\mathrm{n}=3 / 7,5 \%)$.

The effects of passive stretching on hamstring flexibility was assessed by comparing the final evaluation with the initial evaluation between groups. Group A (stretched before and after workout) experienced a significant increase in flexibility of $34.29 \mathrm{~cm}(\mathrm{p}=0.002)$, group B (stretched only before workout) of $31.60 \mathrm{~cm}(\mathrm{p}=0.017)$ and group $\mathrm{C}$ (stretched only after workout) of $22.76 \mathrm{~cm}(\mathrm{p}=0.019)$. In group $\mathrm{D}$, the variation in flexibility of $22.46 \mathrm{~cm}$ was not significant $(\mathrm{p}=0.071)($ Table 1$)$.

Did passive stretching before and after strength training effect flexibility among the participants in groups A, B and $\mathrm{C}$ ?

The influence of passive stretching on hamstring flexibility was assessed by comparing the final evaluation with the initial evaluation between groups. Group A experienced a significant increase in flexibility of $34.29 \mathrm{~cm}$ $(p=0.002)$; group B experienced an increase in flexibility of 
$31.60 \mathrm{~cm}(\mathrm{p}=0.017)$; and group $\mathrm{C}$ experienced an increase in flexibility of $22.76 \mathrm{~cm}(\mathrm{p}=0.019)$. In group $\mathrm{D}$, the variation of flexibility of $22.46 \mathrm{~cm}$ was not significant $(\mathrm{p}=$ 0.071) (Table 1).

Table 1. Analysis of the influence of muscle stretching on flexibility of ischio tibial at Wells Bench in people who workout at the gym. Fortaleza-Ceará

\begin{tabular}{cccc}
\hline $\begin{array}{c}\text { Flexibility } \\
(\mathbf{c m})\end{array}$ & Initial & Final & p \\
\hline GROUP A & $235,1^{\mathrm{a}} \pm 58,88$ & $269,3 \pm 56,59^{*}$ & 0,002 \\
GROUP B & $203,9 \pm 73,89$ & $235,5 \pm 59,92^{*}$ & 0,017 \\
GROUP C & $181,2 \pm 70,28$ & $204,0 \pm 74,39^{*}$ & 0,019 \\
GROUP D & $194,9 \pm 55,46$ & $217,4 \pm 52,53$ & 0,071 \\
\hline
\end{tabular}

a, represents the mean \pm SD of groups. *Statistically significant between groups ( $>0.05$ paired t test). Group A (before and after stretching), B (just before stretching), C (only later) and D (without stretching).

Is there a difference in flexibility increase between the groups? Moreover, is sex or age a factor in increasing flexibility?

When comparing the increase in flexibility in initial and final evaluations among groups $\mathrm{A}, \mathrm{B}, \mathrm{C}$ and $\mathrm{D}$, the results showed no significant differences $(p>0.05)$ (Figure 1).

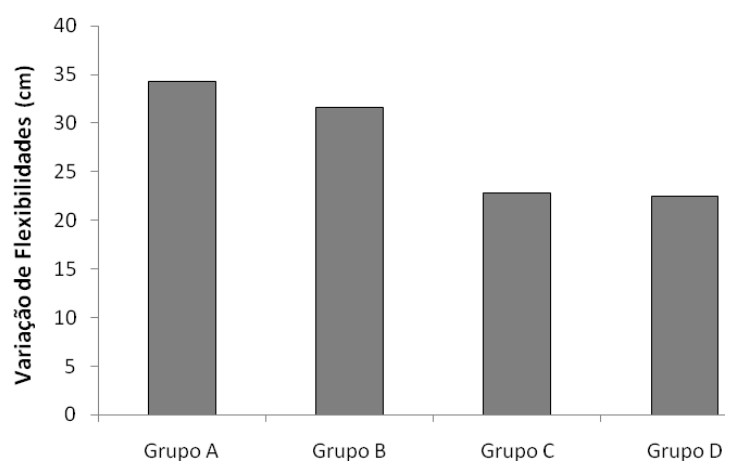

Figure 1. Analysis of the influence of muscle stretching for flexibility in the variation of ischiotibial obtained in the initial and final evaluations in Wells bench in people who workout at the gym. Fortaleza-Ceará

The flexibility of hamstrings was not affected according to the sex and age of participants. The males showed an increase in stretching of $9.1 \mathrm{~cm}$ more than females and participants aged over 26 years were $1.2 \mathrm{~cm}$ longer than the age below 25 years $(\mathrm{p}>0.05)$ (Table 2).

Table 2. Analysis of the influence of gender and age on variations in flexibility ischio tibial at Wells Bench in people who workout at the gym. Fortaleza-Ceará

\begin{tabular}{lccc}
\hline \multicolumn{1}{c}{ Demographic data } & $\mathbf{n}$ & $\begin{array}{l}\text { Flexibility } \\
\text { Variation }\end{array}$ & $\mathbf{p}$ \\
\hline Gender & 16 & $35,4 \pm 29,12$ & 0,29 \\
$\quad$ Male & 24 & $26,3 \pm 24,69$ & \\
$\quad$ Female & & & \\
Age & 31 & $29,7 \pm 28,13$ & 0,90 \\
$\quad$ Under 25 year-old & 9 & $30,9 \pm 21,75$ & \\
$\quad$ Upper 26 year-old & & \\
\hline
\end{tabular}

\section{Discussion}

Several studies have been conducted with the objective of finding the optimal frequency and duration of stretching exercises $[15,16]$. Also, there is a dearth of research linking these exercises with the best time to do stretch.

This study did not find any variation in flexibility between the groups, demonstrating that performing a static stretch for 30 seconds - regardless of when the stretch is performed helps to increase range of motion.

In humans inadequate flexibility is a contributing factor to muscle injuries, particularly the hamstrings [17]. When stretching, a reduction of muscle strength due to increased viscoelasticity of the motor unit resulting in increased muscle length and can prevent injuries if performed consistently before and after exercise programs [18, 19, 20].

However, there is disagreement on this issue as existing research shows that muscle strength is reduced when stretching is performed. This is due to neural and mechanical factors such as decreased activation of motor units, changes in the viscoelastic properties of the muscle and musculotendinous, and changes in the length-tension of the muscle fiber $[21,22,23]$.

Other research shows that the effectiveness of stretching is due more to changes in the individual's tolerance to stretching than to changes in the elasticity of the muscles. They also claim that stretching does not make the hamstrings more or less rigid, but only influences tolerance to stretching $[24,25]$.

Some factors such as gender, age and biological individuality, influence flexibility [26]. Variations such as the female hormonal cycle, serum estradiol, or menstrual phase influence muscle flexibility [27, 28]. However, in this study, age and sex did not influence the increase in range of motion.

Studies also reveal that in relation to sex, women have greater flexibility as compared to men $[29,30]$. However, other authors claim that women tend to have greater body composition, which is a factor that can negatively influence flexibility [31].

The results of this study may contribute to health professionals working in clinical practice and scientific research in determining the best moment to stretch when engaging in physical activity, as there is a lack of reliable references on the effects of stretching on the flexibility of people who work out regularly.

\section{Conclusions}

The data showed that passive stretching resulted in an increase in flexibility in the hamstrings of individuals who worked out particularly those who stretched before and after workout. 


\section{REFERENCES}

[1] Barreto SM, Passos VMA, Giatti L. Healthy behavior among young adults in Brazil. Revista de Saúde Pública 2009;43:9-17.

[2] Kulavic K, Hultquist CN, McLester JR. A comparison of motivational factors and barriers to physical activity among traditional versus nontraditional college students. Journal of the American College Health Association. 2013;61(2):60-6.

[3] Winke MR, Jones NB, Berger CG, Yates JW. Moderate static stretching and torque production of the knee flexors. Journal of Strength and Conditioning Research. 2010;24(3):706-10.

[4] Aguilar AJ, DiStefano LJ, Brown CN, Herman DC, Guskiewicz KM, Padua DA. A dynamic warm-up model increases quadriceps strength and hamstring flexibility. Journal of Strength and Conditioning Research. 2012; 26(4):1130-41.

[5] Marshall PWM, Cashman A, Cheema BS. A randomized controlled trial for the effect of passive stretching on measures of hamstring extensibility, passive stiffness, strength, and stretch tolerance. Journal of Science and Medicine in Sport. 2011; 14(6):535-540.

[6] Costa PB, Ryan ED, Herda TJ, Walter AA, DeFreitas JM, Stout JR, Cramer JT. Acute effects of static stretching on peak torque and the hamstrings-to-quadriceps conventional and functional ratios. Scandinavian Journal of Medicine \& Science in Sports. 2013; 23: 38-45.

[7] Morton SK, Whitehead JR, Brinkert RH, Caine DJ. Resistance training vs. static stretching: effects on flexibility and strength. Journal of Strength and Conditioning Research. 2011;25(12):3391-8.

[8] Herda TJ, Costa PB, Walter AA, Ryan ED, Hoge KM, Kerksick CM, Stout JR, Cramer JT. Effects of two modes of static stretching on muscle strength and stiffness. Medicine and Science in Sports and Exercise. 2011;43(9):1777-84.

[9] Sekir U, Arabaci R, Akova B, Kadagan SM. Acute effects of static and dynamic stretching on leg flexor and extensor isokinetic strength in elite women athletes. Scandinavian Journal of Medicine \& Science in Sports. 2010;20 (2):268-281.

[10] Smith M, Fryer GA. Comparison of two muscle energy techniques for increasing flexibility of the hamstring muscle group. Therapies. 2008;12(4):312-317.

[11] Weppler CH, Magnusson SP. Increasing Muscle Extensibility: A Matter of Increasing Length or Modifying Sensation? Physical Therapy. 2010;90(3):438-449.

[12] Bacurau RFP, Monteiro GA, Ugrinowitsch C, Tricoli V, Cabral LF, Aoki MS. Acute effect of a ballistic and a static stretching exercise bout on flexibility and maximal strength. Journal of Strength and Conditioning Research. 2009;23(1):304-308.

[13] Covert CA, Alexander MP, Petronis JJ, Davis DS. Comparison of ballistic and static stretching on hamstring muscle length using an equal stretching dose. Journal of Strength and Conditioning Research. 2010;24(11):30083014.

[14] Brasil, Resolução CNS nº 196, de 10 de outubro de 1996. Aprova diretrizes e normas regulamentadoras de pesquisa envolvendo seres humanos. Diário Oficial da União 1996;201:21-082.

[15] Fasen JM, O'Connor AM, Schwartz SL, Watson JO, Plastaras CT, Garvan CW, Bulcao C, Johnson SC, Akuthota V. A randomized controlled trial of hamstring stretching: comparison of four techniques. Journal of Strength and Conditioning Research. 2009;23(2):660-667.

[16] McHugh MP, Cosgrave CH. To stretch or not to stretch: the role of stretching in injury prevention and performance. Scandinavian Journal of Medicine and Science in Sports. 2010;20:169-181.

[17] Costa PB, Graves BS, Whitehurst M, Jacobs PL. The acute effects of different durations of static stretching on dynamic balance performance. Journal of Strength \& Conditioning Research. 2009;23(1):141-147.

[18] O’Donovan G, Blazevich AJ, Boreham C, Cooper AR, Crank $\mathrm{H}$, Ekelund $\mathrm{U}$ et al. The ABC of physical activity for health: a consensus statement from the british association of sport and exercise sciences. Journal of Sports Sciences. 2010; 28(6): 573-591.

[19] Herda TJ, Cramer JT, Ryan ED, McHugh MP, Stout JR. Acute Effects of Static versus Dynamic Stretching on Isometric Peak Torque, Electromyography, and Mechanomyography of the Biceps Femoris Muscle. Journal of Strength \& Conditioning Research. 2008;22(3):809-817.

[20] Kieran O'S, Murray E, Sainsbury D. The effect of warm-up, static stretching and dynamic stretching on hamstring flexibility in previously injured subjects. BMC Musculoskeletal Disorders. 2009;10:37-46.

[21] Meroni R, Cerri CG, Lanzarini C, Barindelli G, Morte GD, Gessaga V, Cesana GC, De Vito G. Comparison of active stretching technique and static stretching technique on hamstring flexibility. Clinical Journal of Sport Medicine. 2010;20(1):8-14.

[22] Gama ZAS da, Medeiros CAS de, Dantas AVR, Souza TO de. Influence of the stretching frequency using proprioceptive neuromuscular facilitation in the flexibility of the hamstring muscles. Brazilian Journal of Sports Medicine. 2007;13(1): 33-38.

[23] Manoel ME, Harris-Love MO, Danoff JV, Miller TA. Acute Effects of Static, Dynamic, and Proprioceptive Neuromuscular Facilitation Stretching on Muscle Power in Women. Journal of Strength \& Conditioning Research. 2008;22(5):1528-1534

[24] Torres JB, Conceição MCSC, Sampaio AO, Dantas EHM. Acute effects of static stretching on muscle strength. Biomedical Human Kinetics. 2009;1:52-55.

[25] Franco BL, Signorelli GR, Trajano GS, Oliveira CG. Acute Effects of Different Stretching Exercises on Muscular Endurance. Journal of Strength \& Conditioning Research. 2008; 22(6):1832-1837.

[26] Marshall PWM, Cashman A, Cheema BS. A randomized controlled trial for the effect of passive stretching on measures of hamstring extensibility, passive stiffness, strength, and stretch tolerance. Journal of Science and Medicine in Sport. 2011;14(6):535-540.

[27] Bell DR, Myrick MP, Blackburn JT, Shultz SJ, Guskiewicz KM, Padua DA. The Effect of Menstrual-Cycle Phase on 
Hamstring Extensibility and Muscle Stiffness. Journal of Sport Rehabilitation. 2009;18:1-12.

[28] Aveiro MC, Granito RN, Navega MT, Driusso P, Oishi EJ. Influence of a physical training program on muscle strength, balance and gait velocity among women with osteoporosis. Brazilian Journal of Physical Therapy. 2006;10(4):441-448.

[29] Danneskiold-Samsøe B, Bartels EM, Bulow PM, Lund H, Stockmarr A, Holm CC, Watjen I, Appleyard M, Bliddal H. Isokinetic and isometric muscle strength in a healthy population with special reference to age and gender. Acta Physiologica. 2009;197(S673):1-68.
[30] Cipriani DJ, Terry ME, Haines MA, Tabibnia AP, Lyssanova O. Effect of Stretch Frequency and Sex on the Rate of Gain and Rate of Loss in Muscle Flexibility During a Hamstring-Stretching Program: A Randomized Single-Blind Longitudinal Study. Journal of Strength \& Conditioning Research. 2012;26(8):2119-2129.

[31] Batista LH, Vilar AC, Ferreira JJA, Rebelatto JR, Salvini TF. Active stretching improves flexibility, joint torque, and functional mobility in older women. American Journal of Physical Medicine \& Rehabilitation. 2009;88(10):815-822. 